\title{
ASPECTS OF MULTICULTURALISM IN THE MULOMEDICINA OF VEGETIUS*
}

\author{
M R Mezzabotta† (University of Cape Town)
}

Thanks to the theme for this conference (i.e. Multiculturalism in Antiquity) I have been prompted to look at the Mulomedicina of Vegetius from an angle that has not yet been explored. Like other Latin medical and veterinary treatises this work synthesises Greek theories for Roman use. But the kind of opposition to Greek medical ideas that Cato had voiced in the second century $\mathrm{BC}^{1}$ and that Pliny had echoed 200 years later ${ }^{2}$ is no longer an issue in this late text. The domestic medicine of the early Romans, based on incantations and herbal compounds and applied to both people and animals, had long since assimilated Greek concepts and therapies. ${ }^{3}$ The medical principles underlying the Mulomedicina derive from the "methodist" doctrines introduced by the Greek physician Asclepiades into Rome in the second century $\mathrm{BC}$ or early first century $\mathrm{BC}^{4}$ But Vegetius's Mulomedicina opens a window on to the equine healthcare models of other peoples, usually referred to collectively as "barbarians", but specific mention is made of "the Huns". These management practices appear to function independently of and outside the existing Roman model, thus justifying discussion of them under the label of "multiculturalism". I intend first to set Vegetius' treatise briefly in its literary context, then to examine those passages in the work which have bearing on late Roman contacts with non-Roman hippiatric systems.

Several texts survive from antiquity which deal with the healthcare of animals. ${ }^{5}$ Some of this information crops up in equestrian, biological or agricultural prose treatises, such as Xenophon's Art of Horsemanship, Aristotle's Historia Animalium, ${ }^{6}$ the De Agricultura of Cato, Varro's Res Rusticae, the De Re Rustica of Columella and Palladius' Opus Agriculturae, as well as in parts of Pliny the Elder's monumental encyclopaedic work, the Naturalis Historia. Virgil's Georgics and the Cynegetica of Nemesianus are examples of poems which touch on animal health. But six works focusing exclusively on veterinary matters have come down to us. Five are

* $\quad$ Dr Margaret (Maggie) Mezzabotta was tragically killed in a car accident on 20 February 2000. An early version of this paper was originally presented by her at the biennial conference of the Classical Association of South Africa held at Pretoria in January 1997. It has been revised and updated for publication by Prof D Wardle, drawing on Dr Mezzabotta's unpublished translation of Vegetius' Mulomedicina. This project which remains incomplete was made possible by the funding of a research trip to the United Kingdom by the National Research Foundation in 1998. Quoted in Plin. HN 29.14.

Plin. HN 29.11.

See also Mezzabotta 2001.

4 See Pigeaud 1994, Vallance 1994, Bodson 1984; for his popularity with Celsus, see Von Staden 1996:395.

$5 \quad$ Useful surveys are to be found in Bodson 1984 and Fischer 1988.

6 E.g. Arist. Hist. an. 6.18-27, 7.24, 8.6-10, 9.3-4. 
written in Latin: the three most important are those of Pelagonius, "Chiron" and Vegetius.

(i) The Curae Boum of Gargilius Martialis, an agricultural writer of the third century $\mathrm{AD}$. This is a short tract dealing with bovine ailments but also including treatments for sick horses and mules.

(ii) The De veterinaria medicina of Palladius, a veterinary book discovered in the early years of this century and consisting mostly of excerpts from the veterinary sections of Columella.

(iii) The Ars veterinaria of Pelagonius is a specifically hippiatric text, written in the middle of the 4th century AD. ${ }^{7}$ Most of Pelagonius' recommendations apply to race-horses, the type of equine in which he shows most interest. The work does not survive in its original form $^{8}$ but its design seems clear. Pelagonius cast his work in the form of letters to friends or patrons, in each of which he addressed maladies likely to attack the different parts of the horse. He suggested strings of remedies for individual conditions, drawn largely from the work of predecessors, some of whom he names but leaves others unacknowledged. The epistolatory form was derived from the now lost treatise of Apsyrtus, ${ }^{9}$ a Greek hippiatric writer who appears to have been a practising equine veterinarian. ${ }^{10}$

(iv) The Mulomedicina Chironis of roughly the same period, i.e. mid-fourth century AD. It is the longest, and in many ways the most problematic, of the Latin veterinary monographs. ${ }^{11}$ The name of the author, "Chiron", is probably a pseudonym. ${ }^{12}$ The work is a compilation in 10 books, the first eight of which deal with horses and include references to donkeys and mules as well, while prescriptions and remedies for cattle, sheep, goats and pigs are found in the last two. It is thus broader both in its treatment of equines and in its general veterinary focus than Pelagonius' Ars veterinaria.

(v) Consideration of Pelagonius' treatise and the Mulomedicina Chironis is important for our purposes, as they were the principal sources for the Mulomedicina of Vegetius, which was composed probably in the last years of the 4th century AD, though some scholars have argued for a date in the first part of the 5th century. ${ }^{13}$ This work is the fifth of the extant Latin veterinary treatises.

10 Björck (1944:7-12) argues that Apsyrtus' date, once thought to be Constantinian, now lies within the period 150-250 AD. See also Doyen-Higuet 1984:111-114.

11 It was rediscovered in 1885 and edited and published for the first time in 1901 by Oder.

12 Önnerfors 1988:127.

13 Arguments for the date of Vegetius, which centre on the Epitoma rei militaris, are summarised in Fischer 1981b:215 n.1. Fischer supposes that the veterinary treatise, being more specialised, postdates the military work. Milner (1993:xxv-xxix) argues that the dedicatee of the Epitoma 
(vi) The sixth extant veterinary monograph, the Greek Hippiatrica. This is a collection of excerpts from veterinary writers made in Byzantium in the 10th century AD. They include selections from Greek hippiatric writers whose works are otherwise lost, such as Apsyrtus, as well as Greek translations of passages from Columella, Pelagonius and Vegetius. ${ }^{14}$

To return to Vegetius. It has long been accepted on linguistic and colometric grounds that Vegetius, the author of the Epitoma Rei Militaris, and Vegetius, the compiler of the Mulomedicina, were one and the same man. ${ }^{15}$ His Mulomedicina consists of four books, the first three devoted to horses and mules while the 4th, evidently added later to the original conception at the request of friends, covers the diseases of cattle. In his preface Vegetius names his sources as Pelagonius, Columella, Apsyrtus and "Chiron" and claims also to have consulted all the Latin writers on hippiatric and on medical topics: ${ }^{16}$

His et talibus rationibus invitatus cum ab initio aetatis alendorum equorum studio flagrarem, hanc operam non invitus arripui, ut conductis in unum Latinis dumtaxat auctoribus universis, adhibitis etiam mulomedicis et medicis non omissis (nam mulomedicinae doctrina ab arte medicinae non adeo in multis discrepat sed in plerisque consentit), in quantum mediocritas ingenii patitur, plene ac breviter omnia enucleata digerem causasque et signa morborum declararem.

Induced by these and similar reasons - since from my earliest days I have been fired with enthusiasm for keeping horses - I have seized on this task eagerly, to collect together into a single work all the Latin writers, at least, consulting the veterinary authors also and not omitting the medical writers (for veterinary scholarship does not differ in so many respects from the art of medicine but in most instances agrees with it) and, in so far as my mediocre ability allows, to set out all the essentials fully and concisely and to make known the causes and symptoms of diseases.

His specified sources come in for some censure (Mul. 1 prol. 3): as Columella's focus was farm management he made, in Vegetius' opinion, only fleeting mention of cures for animals, while Pelagonius appeared to Vegetius to be addressing himself to experts, concentrating on remedies to the exclusion of basic information about symptoms and etiology. ${ }^{17}$ Vegetius acknowledges the fuller

was Theodosius I (379-395) rather than than Valentinian III (425-455), the candidate favoured by other scholars, e.g. Goffart (1977) and Birley (1985).

14 The translation of Latin writers into Greek for use by Greek readers reverses the general trend by which, in antiquity, Greek works were translated for the edification of Latin speakers. This suggests that in the field of equine medicine at least, the Romans were held to have made a significant and original contribution, as observed by Fischer (1981b:218-219).

15 Önnerfors 1993:142-143; Milner 1993:xxi.

16 Mul. 1 prol. 6.

17 Fischer (1988:198) observes that Vegetius' charge is groundless. 
treatment and technical superiority of Apsyrtus and "Chiron", on the other hand, but censures their poor Latinity and the confused arrangement of their material. Vegetius writes with a view to setting out in a single work information on diseases, prognoses and remedies in a more comprehensive, eloquent and user-friendly way than did the sum of his predecessors.

The finished design of the treatise, even allowing for some later interpolation (e.g. Mul. 3.28), shows the results of Vegetius' careful rearrangement of his material. Book 1 sets out the symptoms and etiology of morbid conditions to which horses and mules are liable, and prescribes a wide range of therapies, including herbal drenches and enemas, blood-letting, cauterisation, massage and surgery. Book 2 begins by proceeding methodically a vertice usque ad ungulas (Mul. 1.64.2 "from the head to the hooves"), discussing the afflictions to which the various parts of the horse's anatomy are subject. Book 3 is a collection of pharmaceutical recipes, including worm mixtures, caustic ointments, wound-salves and plasters for various conditions. As has been mentioned, Book 4 is devoted to cattle and their ailments.

As a self-advertised compilation, ${ }^{18}$ originality of content is not to be expected from Vegetius' treatise. The principal sources of Books 1 and 2 are Pelagonius (who himself used Columella and Celsus) and the Mulomedicina Chironis. Some of the pharmaceutical prescriptions in Book 3, which Vegetius states are electas ex auctoribus multis, "selected from many authors" (Mul. 3.7.5), may be traced to Pelagonius and to "Chiron", while the provenance of others is unknown. ${ }^{19}$ They may go back to the tradition of herbal preparations used by or under the direction of the paterfamilias, early examples of which are found in Cato's De Agricultura. Like other ancient authors, Vegetius did not feel obliged to name his sources. Most of Book 4 is a recasting of a large portion of Book 6 of Columella's De Re Rustica. The whole work is derivative in content, in common with ancient technical manuals. But not all of it is a paraphrase of earlier work. There are a number of passages, including but not restricted to the prologues to each book, in which Vegetius voices his own concerns. It is to these passages that I now turn, to investigate the evidence for multicultural contacts that the Mulomedicina reveals.

Vegetius emerges as a wealthy landowner who wrote the Mulomedicina for others of his own class. One of his declared motives for willingly undertaking the writing of the treatise is his own love for horses, which he has kept from his earliest days (Mul. 1 prol. 6). In the sixth chapter of the third book, he proclaims himself qualified to pronounce on the characteristics and merits of various breeds of horses because he has detailed personal knowledge of them, gained from his extensive travels (propter tam diversas et longinquas peregrinationes, 3.6.1) through the Empire and from keeping them in his own stables (in nostris stabulis saepe nutrivimus, 3.6.1). Fourteen breeds are alluded to in this chapter alone. It has been

18 Hanc operam arripui, ut conductis in unum Latinis dumtaxat auctoribus universis, adhibitis etiam mulomedicis et medicis non omissis..., plene ac breviter omnia enucleata digerem. (Mul. 1 prol. 6.) 
suggested that he was a bureaucrat charged with procuring military and civil mounts. $^{20}$

What other motives are advanced by Vegetius for undertaking the work, apart from his desire to redress the inadequacies of earlier treatises and his personal enthusiasm for horses? These are revealed particularly in the prologues to each book, in which both apologetic and polemical strands recur. ${ }^{21}$ They centre on Vegetius' dissatisfaction with the state of veterinary medicine in his day, in practice and in writing, and with the neglectful attitude of owners. In the prologues Vegetius gives free rein to his rhetorical powers, elsewhere kept in check by the technical nature of his material. He is anxious to justify veterinary medicine as a discipline as worthy of respect and study as human medicine; he laments the fact that it enjoys less esteem and so fails to attract the most gifted as practitioners or writers. The low status of mulomedicina is aggravated by the high cost of some prescriptions; these are so exorbitant that thrifty owners abandon their sick animals to their misfortunes rather than pay for treatment costs that equal the value of the animal. It would seem, on the other hand, that the professional fees due to the mulomedicus were low; in the opening of the preface to the second book Vegetius attributes the current collapse of the art in part to the exiguitate mercedis, "the meagreness of the rewards". 22 But the losers, as Vegetius points out, are not just the animals, for whom he betrays a sentimental sympathy, but the owners themselves. Their short-sighted frugality could backfire on them and lead to considerable financial loss if a single neglected sick horse of indifferent worth infected a whole herd of valuable animals (Mul. 1 prol. 13).

In the prologue to the second book, Vegetius treats his theme of the collapse of veterinary medicine less discursively:

Mulomedicinae ars iamdudum vitio cupiditatis et exiguitate mercedis nullo studiosius discente collapsa est. Nuper vero exemplo Hunnorum sive gentium aliarum artis ipsius etiam usus intercidit, dum homines, refugientes expensas, barbarorum consuetudinem imitari velle se simulant et incurata animalia hibernis pascuis et negligentiae casibus dedunt. (2) Quae res nulli compendium, plurimis attulit damnum. Primo quod barbaricorum animalium alia natura et ad omnem iniuriam durius corpus est. Deinde quod sic instituuntur a parvulis, ut nec potionem medicinalem requirant et hibernis pascuis vigeant ac sine pernicie frigora pruinasque sustineant. (3) Nostra vero iumenta et mollioris generis sunt et tectis frequentioribus assueta calidisque stabulis imbuta, ubi si indignationem ex aliqua necessitate contraxerint,

20 Milner 1993:xxiii. But I think that Milner has misunderstood the phrase fraudem patriae (Mul. 3.6.1). He takes it as "fraud "practised upon the country".

21 Studied by Zaffagno 1990.

22 See Zaffagno 1990:283 n.45. Zaffagno points out that the professional fees may have seemed steep to the owners but may have been insufficient to attract people to the practice of the art. Mane-clipping, attention to the feet and blood-letting are three procedures for which a maximum fee was set in the Edict of Diocletian, see Adams 1995:61: mulomedico tonsurae et aptaturae pedum in capite uno $X$ sex. deple $<t u>$ rae et purgat $<u>$ rae capitis per singula capita $X$ biginti. (Edict. Dioclet. 7.20-21). This provides the earliest example of the word mulomedicus (AD 301). 
continuo in aliquod genus incidunt morbi. Diligens itaque paterfamilias cum mortibus animalium suorum et [cum] medicinae expensis atque mercedibus faciat rationem, intelleget, unius vilissimi animalis pretium ad multorum, quae sine dubio peritura sunt si curata non fuerint, salutem posse sufficere.

The art of veterinary medicine has long since fallen into a state of collapse through the vice of avarice and the meagreness of the fees, with no one acquiring knowledge of it with any degree of active interest. Indeed recently, following the example of the Huns and other peoples, the practice of the art itself has ceased to exist, while people shrinking from spending money pretend that they are copying the usage of the barbarians and consign their animals untreated to winter pastures and to the mishaps liable to be caused by neglect. (2) This has brought profit to no one and loss to very many. For in the first place, the nature of the animals belonging to the barbarians is different and their bodies are hardier in their resistance to every injury. Next, they are so brought up from the time that they are foals that they do not need any medicinal dose and they thrive in winter pastures and withstand cold weather and frosts without destructive consequences. (3) But our animals are both of a more delicate kind and, being used to more regular shelter and accustomed to warm stables, if ever they have sustained an injury from some exigency, they immediately fall prey to some kind of disease. So the careful paterfamilias should keep an account of the deaths of his animals and compare them with the costs of medicine and fees for treatment, and he will understand that the price of a single, very cheap animal can meet the health needs of many, which will certainly perish if they are left untreated.

Because the financial rewards are deemed insufficient, nullo studiosius discente, "noone devotes the requisite study to the discipline". ${ }^{23}$ But bad as things have been, they have lately (nuper) become worse: "Lately" he laments, "even the practice of the art itself has died, under the influence of the model offered by the Huns, or of other barbarian races, while people shrinking from spending money pretend that they are following the practice of barbarians and consign their animals, untreated, to winter pastures and to the accidents that arise from negligence". ${ }^{24}$ But, objects Vegetius, barbarian horses and iumenta nostra ${ }^{25}$ differ significantly in physique and upbringing. The horses of the barbarians are hardier than the Roman horses and from the time they are foals they are accustomed to manage without medication. They thrive in winter pastures and suffer no ill effects from the cold and frosts. Roman mounts, on the other hand, are more delicate. They are used to shelter and to warm stables (Vegetius presumably has their winter care specifically in mind). If they were to be left out in the open in winter to fend for themselves, any minor ailment might cause them to develop a serious disease immediately. The difference in their constitutions

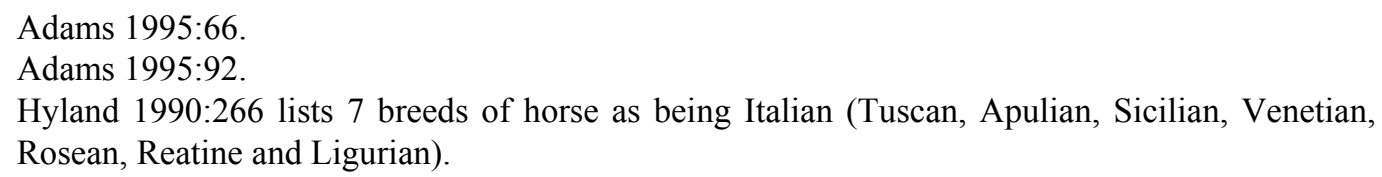


which Vegetius mentions was not necessarily innate but a result of conditioning; as Lindner observes in the case of the Hunnic horse, "[t]he horse of the Huns was bred for the steppe, a different breed from the stall-fed Roman horse". ${ }^{26}$ The argument of this passage then continues on familiar lines, advising that the diligens paterfamilias (Mul. 3 prol. 3) should not be tempted to adopt the false economy of imitating nonRoman systems of equine management.

It is clear that Vegetius regards the barbarian way as "a form of negligence". ${ }^{27}$ He does not enquire into the underlying rationale. Perhaps the barbarians entertained the fatalistic notion criticised by Vegetius in the prologue to the third book, whereby animals are left untreated on the grounds that if they are fated to recover they will do so, while if they are destined to die, no amount of treatment will help (Mul. 3 prol. 2 $3)$. Vegetius appears to accept the validity of the statement that horses reared under barbarian methods do not run undue risks to their health. But he takes pains to point out if barbarian breeds are kept under Roman conditions, they must be treated like Roman horses. In chapter 6 of Book 3 he addresses the topic of the lifespans of various breeds of horses, for the benefit of those of his readers who, like himself, owned a variety of breeds. He condemns as false the frequens opinio (Mul. 3.6.1) that barbarian breeds should not be given any medication on the grounds that nature ensures their recovery and any treatment would, in fact, be harmful. If barbarian horses were kept in crowded stables under the Roman system, and not treated if they fell ill, they might infect all the other animals.

Did the barbarians really not give their animals any veterinary attention? I have already drawn attention to the polemical nature of the prologues. Vegetius constructs his arguments on a series of well-calibrated oppositions: human medicine/ veterinary medicine, man/animal, profit/loss, care/neglect, Roman/Barbarian. It may well be that Vegetius' pronouncement on this last set of oppositions exaggerates to serve his rhetoric. Indeed, his own text contradicts his picture of barbarian animals being left untreated.

Sed si coxam eiecerit vel emoverit, quod a mulomedicis dicitur filum laesisse, certior faciliorque curatio rei inventa dicitur a barbaris. (5) Nam claudum animal in sole constituunt, vino et oleo calefacto colefium ipsum, hoc est iuncturam coxae, diutissime confricant, donec sudet. Tunc de loro longiore vel funiculo grosso pravam coxam alligant. Unus animal capistro trahit, ut sensim currat, alius lorum vel funem tenens laxum sequitur et subito, dum animal currit, recta ad se ipsius impetu retrahit. Si sonuerit, scias loco suo redisse, et paulisper cessabis; post sensim deambulando temptabis. (6) Et si rectum pedem ponat et non claudicet, ulterius animal non vexabis, sed per triduum fomentabis de calida verbenacea, post causticum induces. Quodsi prima die reponi iunctura non potuerit, secunda die vel tertia simili ratione coxam saepius trahes, donec revertatur ad locum. ${ }^{28}$

\footnotetext{
Lindner 1981:12.

Adams 1995:93.

Mul. 2.82.4-6.
} 
But if an animal has thrown its hip out or dislocated it, which is called by veterinary practitioners "injuring the thread", a surer and easier cure for the condition is said to have been discovered by the barbarians. (5) For they place a lame animal in the sun, they rub the colefium, that is, the hip joint, for a very long time with wine and warmed olive-oil, until it sweats. Then they tie the crooked hip to a longer-than-usual rein or a thick rope. One person pulls the animal with a halter, to make him build up gradually to a run, another person follows, holding the rein or the rope slack and suddenly, while the animal is running, pulls the hip straight back toward himself by the animal's own impetus. If it makes a noise, you may know that it has gone back into its place, and you will stop for a little while; then you will test it by walking up and down slowly. (6) And if it puts its foot down straight and is not lame, you will not trouble the animal further but will bathe it for three days with hot water in which vervains have boiled, then spread on a caustic salve. But if the joint cannot be put back into position on the first day, on the second day or on the third, exert traction on the hip in a similar way at frequent intervals, until it returns to its position.

Vegetius describes a treatment for hip-dislocation "said to have been invented by the barbarians" and which he recommends as more successful and easier than the lengthy complicated procedure he had outlined in the passage immediately preceding this extract. It is a form of distal traction. After warming and relaxing the afflicted area by placing the animal in the sun and massaging the joint, they try to make the hip snap back into place. One man leads the horse while another follows, holding a longish rope tied to the upper part of the femur. The horse is encouraged to run and the man with the rope jerks it back towards himself. A clicking sound indicates that the dislocation has been corrected. ${ }^{29}$ The rest of the information about treatments for dislocation of the hip, a common hazard, is derived from the Mulomedicina Chironis. ${ }^{30}$ Vegetius has learned of it from some other source. The passage shows that in the case of hip displacement, at least one grouping of barbarians actively intervened, developing a therapy that was successful enough to pass into the general repertoire of Roman remedies.

But veterinary first aid by barbarians is one thing: what about dosing with pills and potions? It would appear from Vegetius's own testimony, again in a passage that is not found in Vegetius's identified sources, that pharmaceutical treatments were not unknown to them.

Barbarorum usus invenit salutare remedium: radicem herbae, cui nomen est inula, quam Campanam plerique appellant, colliges et in umbra siccabis; post deteres, in pulverem rediges, ex quo terna maiora coclearia in singulis

29 Adams (1995:398-399) discusses the technical terminology used in the passage.

30 Mul. Chir. 43, 44, 588. 
sextariis vini veteris pridie infundes, et cum bene agitaveris claudes, ne odor herbae salutaris exhalet: per os triduo vel quot volueris diebus digeres. ${ }^{31}$

The practice of the barbarians has discovered a health-giving remedy [against coughing]: gather the root of the herb whose name is inula, which most people call elecampane, and dry it in the shade: then grind it up, reduce it to powder, pour three largish spoonfuls of this in a sextarius each of old wine the day before and when you have given it a good stir, seal it up to stop the smell of the health-giving herb from escaping; give it by mouth for three days or for as many days as you wish.

Vegetius records a number of prescriptions for coughs and chronic respiratory conditions $^{32}$ that include a salutare remedium discovered by "barbarians" from empirical observation. The active ingredient in this prescription is elecampane, known as Inula Helenium L. by the Linnaean binomial system of nomenclature and which even today is used in herbal medicine for coughs and respiratory ailments. ${ }^{33}$ But the rest of the recipe fits unexceptionally into the general pattern of GraecoRoman pharmaceutical prescriptions. The root is to be gathered, dried, reduced to powder, then measured out to be given in a drench in old wine, the usual medium of administration in Graeco-Roman medicine, after being stored for a day in a closed container. The "barbarians" who invented this cough mixture evidently live a settled existence. I conclude from the discrepancy between Vegetius' claim in the second prologue and the evidence contained in the body of his work that for Vegetius, there were "barbarians" and "barbarians". Sense can be made of the apparent contradiction only if we assume that Vegetius differentiated in his mind between those non-Greek or non-Latin speakers living in settled communities, like the Persians, and those who, like the Huns, lived a nomadic existence. So the barbarorum consuetudo of the second prologue, which Vegetius condemns as dangerously negligent, is associated specifically with the Huns, and the gentes aliae are other nomadic tribes.

The literary records of the time show that the imaginations of Vegetius's contemporaries were fired by the Huns themselves and their habits. ${ }^{34}$ Vegetius's interest was taken by their horses, of which he had personal knowledge.

In permutandis vel distrahendis equis maximam fraudem patriae solet afferre mendacium. Volentes enim carius vendere generosissimos fingunt. Quae res nos compulit, qui propter tam diversas et longinquas peregrinationes equorum genera universa cognovimus et in nostris stabulis saepe nutrivimus, uniuscuiusque nationis explicare signa vel merita. (2) Nam ut viliora ministeria taceamus, equos tribus usibus vel maxime necessarios constat:

31 Mul. 22.134.3.

32 Such as "broken-wind", "the heaves". Broken-winded horses appear to exhale in two stages, by "an initial passive normal expiratory movement followed by an active contraction of the chest and abdominal muscles to expel the remaining air"; Miller \& West 1953:115; Adams 1995:305306.

33 Grieve 1931:278-282.

34 E.g. Amm. Marc. 31.2.1-10; Jerome Ep. 70.77. On the Huns, see Thompson 1996. 
proeliis circo sellis. Ad bellum Huniscorum longe prima docetur utilitas patientiae, laboris, frigoris, famis; (3) Toringos dehinc et Burgundiones iniuriae tolerantes, tertio loco Frigiscos non minus velocitate quam continuatione cursus invictos, postea Epirotas, Samaricos ac Dalmatas, licet contumaces ad frena, armis habiles asseverant. (4) Curribus Cappadocum gloriosa nobilitas, Hispanorum par vel proxima in circo creditur palma. Nec inferiores prope Sicilia exhibet circo, quamvis Africa Hispani sanguinis velocissimos praestare consueverit. Ad usum sellae Persis provinciis omnibus praestat, equos exhibet patrimoniorum censibus aestimatos, ad vehendum molles et impigros, incessus nobilitate pretiosos. Sequuntur Armenii atque Sofoeni: in qua parte nec Epirotas Siculosque despexeris, si mores ac pulchritudo non deserat. (5) Huniscis grande et aduncum caput, extantes oculi, angustae nares, latae maxillae, robusta cervix et rigida, iubae ultra genua pendentes, maiores costae, incurva spina, cauda silvosa, validissimae tibiae, parvae bases, plenae ac diffusae ungulae, ilia cavata totumque corpus angulosum, nulla in clunibus arvina, nulli in musculis tori, in longitudine magis quam in altitudine statura propensior, venter exhaustus, ossa grandia, macies grata et quibus pulchritudinem praestet ipsa deformitas: et animus moderatus prudens et vulnerum patiens. (6) Persae statura et positione a ceteris equorum generibus non differunt plurimum, sed solius ambulaturae genere: nam quadam gratia discernitur e ceteris: gradus est minutus, celer et qui sedentem delectet et erigat, nec arte doceatur sed naturae velut iure praestetur. (7) Inter tolutarios enim et eos, quos totonarios vulgus appellat, ambulatura eorum media est et cum neutris sit similis, habere creditur aliquid ab utroque commune. (8) His, sicut probatum est, in brevi amplior gratia, in prolixo itinere minor patientia, animus superbus et nisi labore subiugetur assiduo, adversum equitem contumax; mens tamen prudens et quod mirum sit in tanto fervore, cautissima decoris, incurvata in arcum cervix, ut mentum recumbere videatur in pectore. ${ }^{35}$

In buying or selling horses, falsehood tends to produce serious deceit with regard to the country of origin. For wishing to sell them more dearly they represent them as being of very noble stock. This fact compels us, who have learnt about all the breeds of horses due to our extensive travels abroad and have often kept them in our own stables, to set out the characteristic merits of [the horses of] each nation. (2) For to say nothing of their more mundane services, it is agreed that horses are absolutely necessary for three uses: for war, for the race-course and for the saddle. For war, the horses of the Huns are by far the most useful, by reason of their endurance of hard work, cold and hunger; (3) next the Thuringian and the Burgundian horses are tolerant of harsh treatment, in the third place the horses of the Frigisci are unbeaten not less in the speed of their galloping as in their ability to gallop without a break, 
then the horses of Epirus, Samaria ${ }^{36}$ and Dalmatia, although they are stubborn to the bridle, they are suitable for war. (4) The superiority of the Cappodocian horses for chariots is renowned, while an equal prize, or one very close, in the circus is reckoned to go to the Spanish horses. Nor does Sicily produce horses inferior [to these] for the circus, although Africa is accustomed to offer very swift horses of Spanish blood. Persia in all its provinces excels for saddle use, it supplies horses valued at the worth of ancestral estates, soft and energetic to ride, of great value because of the excellence of their step. The horses of the Armenians and the Sofoeni come next: in this category: you should not despise the horses of Epirus and Sicily, if temperament and looks do not desert them. (5) The Hunnish horses have a large, hooked head, protuberant eyes, narrow nostrils, broad cheeks, a strong, inflexible neck, manes hanging down below the knees, larger-than-usual ribs, a bent spine, a bushy tail, very strong cannons, small bases to their feet, full, spreading hooves, hollow flanks and the whole body angular, no fat on the buttocks, no bulges in the musculature, their physical configuration tends more towards length than height, a drawn belly, large bones, a pleasing leanness and their very ugliness itself constitutes their beauty: their disposition is moderate, sensible and tolerant of wounds. (6) Persian horses do not differ very much in their stature and posture from other breeds of horses, but in the manner of their walking alone: for they are distinguished from other horses by a certain gracefulness: their step is small, quick and one which charms and uplifts the rider, it is not taught by art but is given them by a law of nature, so to speak. (7) For their pace is midway between the high-stepping pacers (tolutarii) and the ones which the common people call gallopers (totonarii) ${ }^{37}$ and although it is like neither, it is thought to have something in common with both. (8) These, as has been proved, have more gracefulness on a short journey and less endurance on a long one, their disposition is proud and, if not crushed by constant work, rebellious towards the rider; their mind, however, is circumspect and, what is amazing in such great vehemence, most careful to maintain their elegant looks, the neck being curved into a bow, so that the chin appears to rest on the chest.

Vegetius lists the breeds of horses that are best for each of the three prestigious activities for which horses were used, war, racing and individual transport. Hunnic horses make the best war mounts, Cappodocian horses excel in the circus while the most graceful and comfortable riding horses come from Persia. The chapter ends with extended descriptions of the Hunnic charger and the Persian saddle-horse.

Vegetius's portrait of the Hunnic horse is "a true nightmare of an equine" evoking Don Quixote's Rosinante as Ann Hyland suggests. ${ }^{38}$ Ammianus Marcellinus

36 Or Sarmatia. The alternative Sarmatia is clearly preferable given the locations juxtaposed. The Sarmatians were renowned for their cavalry. See e.g. Sulimirski 1970:26-31.

37 On "high-stepping pacers" and "gallopers" see Adams 1990:597.

38 Hyland 1990:27. 
called the Huns' horses "hardy but ugly" (quidem sed deformibus, Amm. Marc. 31.2.6). It is interesting that Vegetius' description of the conformation and features of the Hunnic horse, contradicts in almost every respect the standard account of the characteristics of the ideal stallion that turns up in Varro, Columella, Palladius, the Mulomedicina Chironis and in Pelagonius. ${ }^{39}$ The Hunnic horse had a large, hooked head (i.e. was Roman-nosed), staring eyes, a strong but inflexible - therefore ungraceful - neck, a mane hanging down to below the knees (too much of a good thing), a crooked backbone (i.e. he was roach-backed), large, spayed-out hooves, skinny hindquarters, a bushy tail (the Romans thought these were ugly), an absence of pleasingly-bulging muscles and his conformation tends to length rather than height. To a Roman eye the Hunnic horse seemed as hardy and hideous as its riders. But, says Vegetius, its very ugliness constitutes its beauty. On the credit side, the animal's temperament was suited to its function as a war-horse, being fairly spiritless and able to tolerate hard riding, cold, hunger and wounds.

I began this essay by claiming that the Mulomedicina opened a window on to the equine management practices of the Huns and other non-Roman peoples. It might be said that because of the slenderness of the evidence - a few sentences - I have been able to open the window only a crack. But I think we have seen enough to grasp the broad characteristics of the Huns' hippiatric system - or lack of it - to understand that the nomadic habits of the Huns during the early period of their contact with the Romans precluded the provision of special feeding and warm winter stables. Their horses had to forage for themselves from what was available. No wonder they were lean. In the absence of the relatively sophisticated trauma therapies practised by Roman mulomedici a Hunnic battle mount, faute de mieux, simply had to be vulnerum patiens. It is unlikely that the picture was one of total neglect but it contained sufficient truth to be mobilised by Vegetius to serve his rhetorical purposes. At a time when the status and practice of Roman veterinary medicine was in decline, some of Vegetius's contemporaries attempted to save money by adopting another model with which they had become familiar, the Hunnic way of neglect. In order to deter his readers from following this economically ruinous course and to convince them to accord hippiatric medicine its due dignity, Vegetius uses the example of the Huns, a topic guaranteed to grasp the attention of his readers, as a model of "otherness" to be shunned at all costs.

\section{BIBLIOGRAPHY}

Adams, J N 1995. Pelagonius and Latin veterinary terminology in the Roman empire. Leiden: Brill.

Birley, E 1985. The dating of Vegetius and the Historia Augusta. In Bonner Historia Augusta Colloquium 1982-1983, 57-67. Bonn: Habelt.

39 Varro Rust. 2.7.5; Columella Rust. 6.29.2-3; Palladius 4.13.2.7; Mul. Chir. 779-780; Pelagonius 2; Geopon. 16.1.9 (= Anatoli de equis, $C H G$ 11, p. 326); Isid. Orig. 1.45-47. 
Björck, G 1944. Apsyrtus, Julius Africanus et l'hippiatrique grecque. Uppsala Universitets Arsskrift 4.

Bodson, L 1984. La médécine vétérinaire dans l'antiquité romaine. Problèmes, composantes, orientation. Ethnozootechnie 34:3-12.

Doyen-Higuet, A-M 1984. The Hippiatrica and Byzantine veterinary medicine. Dumbarton Oaks Papers 38:1111-1120.

Fischer, K-D 1981a. Pelagonius on horse medicine. In Cairns, F (ed.), Papers of the Liverpool Latin Seminar Third Volume, 285-303. ARCA Classical and medieval texts, Papers and Monographs 7. Liverpool: F. Cairns.

Fischer, K D (ed.) 1980. Pelagonii Ars Veterinaria. Leipzig: Teubner.

Fischer, K D 1981b. The first Latin treatise on horse medicine and its author Pelagonius Saloninus. Medizinhistorisches Journal 16:215-226.

Fischer, K D 1988. Ancient veterinary medicine. Medizinhistorisches Journal 23:191-209.

Goffart, W 1977. The date and purpose of Vegetius' de Re Militari. Traditio 33:65100.

Grieve, M 1931 (1992 rev. ed.) A modern herbal. London: Tiger Books International.

Hyland, A 1990. Equus: The horse in the Roman world. London: Batsford.

Lindner, P P 1981. Nomadism, horses and Huns. Past \& Present 92:3-19.

Lommatzsch, E (ed.) 1903. P. Vegeti Renati Digestorum Artis Mulomedicinae Libri. Leipzig: Teubner.

Mezzabotta, M R 2001. Ethno-veterinary remedies in the Elder Cato. Acta Classica 51 (forthcoming).

Miller, W C \& West, G P 1953. Black's veterinary dictionary. London: Black.

Milner, N P (trans.) 1993. Vegetius: Epitome of military science. Liverpool: Liverpool University Press.

Oder, E (ed.) 1901. Claudii Hermeri Mulomedicina Chironis. Leipzig: Teubner.

Önnerfors, A 1988. Zaubersprüche in Texten der römischen und frühmittelalterlichen Medizin. Centre Jean-Palerne, Mémoires VIII (Sainte-Étienne), 113-156.

Önnerfors, A 1993. Zu Person und Werk des Publius Flavius Vegetius Renatus. Vetenskapssocietetens $i$ Lund Arsbok 1991 (=Yearbook of the New Society of Letters at Lund), 142-173. Lund: Lund University Press.

Pigeaud, J 1994. L'introduction de méthodisme à Rome. ANRW 2.37.1:565-599.

Sulimirski, T 1970. The Sarmatians. London: Thames and Hudson.

Thompson, E A 1996. The Huns. Rev. ed. The People of Europe. Oxford: Blackwell.

Vallance, J 1994. The medical system of Asclepiades of Bithynia. ANRW 2.37.1:646690.

Von Staden, H 1996. Liminal perils. Early Roman reception of Greek medicine. In Ragep, F J \& Ragep, S P (eds.) Tradition, transmission, transformation, 369418. Leiden: Brill.

Zaffagno, E 1990. I prologi della Mulomedicina di Publio Vegezio Renato. In Santini, C \& Scivoletto, N (eds.), Prefazioni, prologhi, proemi di opere tecnico-scientifiche latine, vol. 1:259-291. Rome: Herder. 